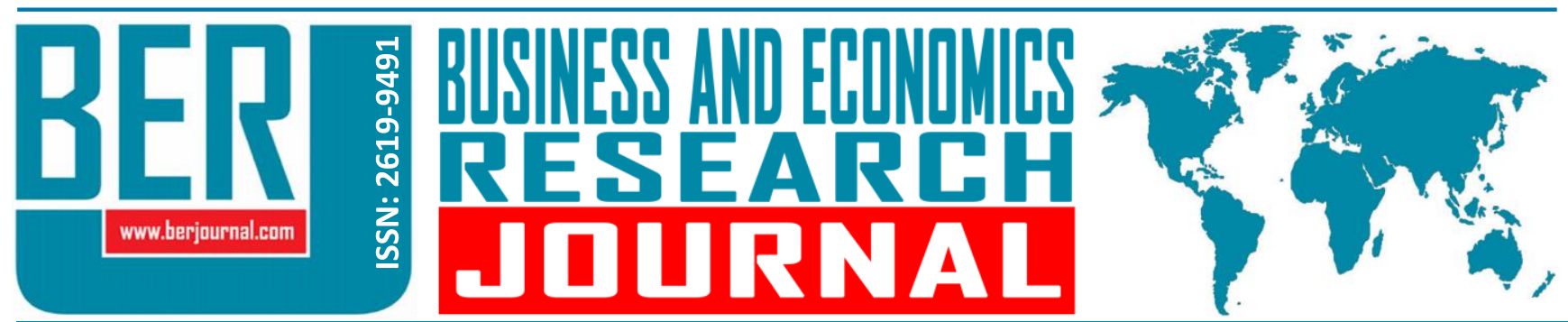

Business and Economics Research Journal Vol. 9, No. 4, 2018, pp. 889-900 doi: 10.20409/berj.2018.145

\title{
The Effects of Social Responsibility Activities on Stakeholders' Purchase Intention
}

\author{
Cagla P. Bozoklu
}

Abstract: Following the anti-globalization movement, an ideology, which reflects a climate of defiance toward businesses, has spread out to the societies. Thereby, corporates have begun to engage in socially responsible behaviors not only to meet stakeholder expectations, but also to achieve their goal-oriented considerations. This research aims to analyze effects of corporates' social and environmental responsibility activities on the purchase intentions of stakeholders by integrating the perspectives of obligations. Corporate Reputation Scale was conducted to most important stakeholder groups (customers, employees, rival corporates' employees and public) by using purposive and random sampling methods. For the reliability measurement, a pre-test was conducted on 112 participants and during the research 680 questionnaires were gathered. Results reveal that the reflections of CSR image can differ according to the market. In the banking market, both making efforts for creating new jobs (economic obligation), taking responsibility on environmental issues (social obligation) and reducing its profits to ensure a clean environment (ethical obligation) are valuable. In the air transportation market social and economic obligations are perceived as significant by stakeholders whereas in the communication market social and ethical obligations are perceived as significant.

Keywords: Social

Responsibility, Environmental Responsibility, Stakeholder, Purchase Intention, Turkey

JEL: G21, L10, L21, L80, M14, Q56

$\begin{array}{ll}\text { Received } & : 27 \text { September } 2018 \\ \text { Revised } & : 12 \text { October } 2018 \\ \text { Accepted } & : 19 \text { October } 2018 \\ & \\ \text { Type } & : \text { Research }\end{array}$

\section{Introduction}

In the past decade mankind have observed the serious development of the anti-globalization movement, shareholder activism and corporate governance reform. Although this trend had begun with a relatively small group, it has transformed to an ideology and/or a lifestyle which reflects a climate of defiance toward businesses. Perhaps in response to this growing suspicion, some leading companies have openly profiled themselves as socially responsible (Maignan \& Ferrel, 2004).

Corporates engage in socially responsible behaviors not only to meet external obligations such as regulatory compliance and stakeholder expectations, but also due to achieve their goal-oriented considerations such as gaining competitive advantage and improved stock market performance (Bansal \& Roth, 2000; Drumwright, 1994).

Although it is commonly accepted that the main aim in for profit organizations is to generate profit for its shareholders, depending on the idea of social contract there should be agreement between businesses and society for appeasing a broader group of interested stakeholders (O'Donovan, 2002; Coupland, 2006: 867). 
As the transformation of priorities, it is suggested that purchase behavior of individuals who show sensitivity on social and environmental issues has changed. Depending on that assumption, a research which is based on the three main obligation kinds in terms of social and environmental responsibility literature was conducted. As service industry has a more vulnerable structure within the context of the stakeholders' negative judgements, three main service markets such as banking, communication and air transportation are chosen as decision units. These markets can also provide valuable insights for the significance of CSR activities in a dynamic, competitive environment due to they contain both national and international corporates.

In Turkish literature, the effects of reputation and social responsibility activities on purchase behavior (Öztürk \& Çakır, 2014), purchase intention (Demirgüneş, 2015; Yorulmazer \& Doğan, 2017), brand image (Özdemir, 2009) and brand preference (Kardeş, 2011) has been examined. However, this research contributes more unique aspects compared to current researches by reason of the fact that it is structured according to economic, social and ethical obligations carried out in a manner of CSR activities.

In this paper, the concept of corporates' social and environmental responsibility activities has discussed at first. After stating methodology and analyses, discussion and conclusion of findings have presented depending on the literature.

\section{Social and Environmental Responsibility Activities of Corporates}

Corporate social responsibility (CSR) defined as a company's status and activities with regard to its perceived obligations toward society (Brown \& Dacin, 1997; Sen \& Bhattacharya, 2001). CSR promotes a company's strategic efforts to create shared value, or the creation of "economic value in a way that also creates value for society by addressing its needs and challenges" (Porter \& Kramer, 2011: 64). It can be regarded as an instrument that develop positive social responsibility images (Brown \& Dacin, 1997; Sen \& Bhattacharya, 2001). Over these years, companies like Microsoft, Johnson \& Johnson, Unilever, Google and Nestle' have also launched programs to reduce their environmental footprints (Janssen et al., 2015:184).

Companies' CSR efforts can be manifested by a variety of issues such as diversity, education, economic development, the environment, and human rights (Kotler et al., 2012). Wood (1991) roughly emphasized three main types of CSR processes: environmental management, issues management, and stakeholder management.

CSR concept has literally developed in three stages. In the early stage of this development, it was considered as limited to the context of social obligations. According to Carroll (1979), social obligations can be classified as economic obligations (be productive and economically viable), legal and ethical obligations (follow the law and acknowledged values and norms), and philanthropic obligations (proactively give back to society).

Beginning with the year of 1995, Clarkson (1995), Freeman (1984) and some other scholars suggest that businesses are not responsible toward society as a whole but only toward those who directly or indirectly affect or are affected by the company's activities. This idea triggered the development of stakeholder theory. Henriques and Sadorsky (1999) considered stakeholders in four main categories such as organizational (e.g., employees, customers, shareholders, suppliers), community (e.g., local residents, special interest groups), regulatory (e.g., municipalities, regulatory systems), and media stakeholders. However, in the same years, researchers like Donaldson and Preston (1995) and Swanson (1995) stated an ethics-driven view of CSR that asserts the rightness or wrongness of specific corporate activities independently of any social or stakeholder obligation.

On the other hand, some researchers approached to CSR in terms of corporate social responsiveness (e.g. Wartick \& Cochran, 1985; Wood, 1991; Ackerman, 1975). Ackerman (1975) explained the three main activities as monitoring and assessing environmental conditions, attending to stakeholder demands, and designing plans and policies aimed at enhancing the firm's positive impacts within the context of responsiveness. 
Depending on these focal points, some academic researches has aimed to demonstrate the positive effects of CSR on business activities such as enhancing consumers' company evaluations and purchase intentions (Sen \& Bhattacharya, 2001), whereas others have favored how corporates successfully manage CSR activities.

Literature demonstrates that CSR has a halo effect on consumer judgments, such as the positive evaluations of products that socially and/ or environmentally responsible (Klein \& Dawar, 2004). CSR is specifically attractive to consumers who are motivated to define their selves by the green brand values in turn, support for the socially responsible company.

According to Sen and co-others (2016: 70), consumers not only favor products which socially responsible (Sen \& Bhattacharya, 2001; Trudel \& Cotte, 2009; Chernev, 2015), but also prefer them primarily under different circumstances (Auger et al., 2008; Du \& Bhattacharya, 2008; Krishna \& Rajan, 2009; Henderson \& Arora, 2010; Du et al., 2011; Andrews et al., 2014;). How much consumers know about a company's CSR actions (Du \& Bhattacharya, 2008; Servaes \& Tamayo, 2013), and how much and what they elaborate on when thinking about these actions are main drivers of their responses (Menon \& Kahn, 2003). However, there are also researches concluded that consumers do not always act in line with their CSR-guided purchase intentions (Auger et al., 2008; Carrington et al., 2014).

Therefore, for a company with strong CSR associations an important issue to assess is how and when its CSR engagements affect its stakeholders' perceptions (Janssen, Sen \& Bhattacharya, 2015:185). Although some researchers argue that the effects of integrated reputation on sales is stronger when the company's reputation is based on its core competencies (e.g. product quality or innovation) rather than on perceptions of its social responsibility image (Fombrun \& Van Riel, 2004: 9). Still, a wide range of stakeholders -including consumers, employees, public, companies' own employees, and rival companies' employees- expect CSR commitments from companies (Cone Communications \& Echo Research, 2013).

This research adopts the approach which focuses the effects of CSR image of corporates on business activities by integrating the perspectives of both social, economic and ethical obligations.

\section{Method}

The aim of this research is to test whether social and environmental responsibility image of corporates effects the purchase intention. The hypotheses are:

$H_{0}=$ There is no statistically meaningful difference in stakeholders' product purchase intention depending on the social and environmental responsibility image of banking market in Turkey.

$H_{0}=$ There is no statistically meaningful difference in stakeholders' product purchase intention depending on the social and environmental responsibility image of civil air transportation market in Turkey.

$H_{0}=$ There is no statistically meaningful difference in stakeholders' product purchase intention depending on the social and environmental responsibility image of communication market in Turkey.

Corporate Reputation Scale developed by G. Walsh and S. Beatty (2007) was conducted to most important stakeholder groups such as customers, employees, rival corporates' employees and public by using purposive and random sampling methods. This scale was translated to Turkish language and then, second opinions were gathered from academics who are specialized in the fields of English Language and Literature, Turkish Language and Literature, marketing, and management. Random sampling method was conducted to customers and public whereas purposive sampling method was preferred for employees and the rival corporates' employees. This scale has been applied in 709 researches in foreign literature. According to that, it was accepted as reliable instrument. Nonetheless, a pre-test was conducted to 112 participants for the reliability measurement, during September in the year of 2017. Cronbach Alpha is calculated as .913 for all Likert items. The scale consists of 3 five-point Likert items for the evaluation of social and environmental responsibility image of corporates. They are:

Q1: Company seems to make an effort to create new jobs (economic obligation). 
Q2: Company seems to be environmentally responsible (social obligation).

Q3: Company would reduce its profits to ensure a clean environment (ethical obligation).

On the other hand, 5 categorical items, measured consumer purchase preferences, are presented as follows:

1: I have never purchased this corporate's products and I will never purchase.

2: I have never purchased this corporate's products but I may purchase in the future.

3: I sometimes purchase this corporate's products.

4: I often purchase this corporate's products.

5: I always prefer this corporate's products.

As mentioned before, it is assumed that service industry has a more vulnerable structure within the context of stakeholders' negative judgements. Three main service markets such as banking, communication and air transportation are chosen as decision units. These markets can also provide valuable insights for the significance of CSR activities in a dynamic, competitive environment due to they contain both national and international corporates. Varied stakeholders of four private banks, three communication companies and two air transportation companies were reached during the data collection process. The corporates can be seen in Table 1. During the research, conducted during December 2017, 708 scales were gathered. But it was concluded with the number of 680 scales in due to several missing answered questionnaires. IBM SPSS Statics 22.0 was employed for statistical analyses.

Table 1. Frequency of Stakeholder Groups and Brands of Corporates

\begin{tabular}{|c|c|c|c|c|c|c|}
\hline Market & $\begin{array}{l}\text { Brands of } \\
\text { Corporates }\end{array}$ & $\begin{array}{c}\text { Customer } \\
\mathbf{n}\end{array}$ & $\begin{array}{c}\text { Employee } \\
n\end{array}$ & $\begin{array}{c}\text { Public } \\
n\end{array}$ & $\begin{array}{c}\text { Rivals' } \\
\text { Employee } \\
n\end{array}$ & $\begin{array}{c}\text { Total } \\
\mathbf{n}\end{array}$ \\
\hline \multirow[t]{5}{*}{ Banking } & Akbank & 15 & 17 & 20 & 5 & 57 \\
\hline & Garanti Bankası & 16 & 2 & 21 & 1 & 40 \\
\hline & $\begin{array}{l}\text { Türkiye İş } \\
\text { Bankası }\end{array}$ & 12 & 12 & 15 & 10 & 49 \\
\hline & $\begin{array}{l}\text { Yapı Kredi } \\
\text { Bankası }\end{array}$ & 8 & 36 & 17 & 1 & 62 \\
\hline & Total & 51 & 67 & 73 & 17 & 208 \\
\hline \multirow[t]{4}{*}{ Communication } & Türk Telekom & 19 & 4 & 8 & 2 & 33 \\
\hline & Turkcell & 57 & 12 & 27 & 4 & 100 \\
\hline & Vodafone & 77 & 17 & 34 & 5 & 133 \\
\hline & Total & 153 & 33 & 69 & 11 & 266 \\
\hline \multirow[t]{3}{*}{ Air Transportation } & Pegasus & 18 & 28 & 1 & 4 & 51 \\
\hline & Turkish Airlines & 94 & 22 & 26 & 13 & 155 \\
\hline & Total & 112 & 50 & 27 & 17 & 206 \\
\hline
\end{tabular}

In addition, these corporates operate various kinds of CSR activities and they promote them on their web-site. A content analysis of these statements was done by means of grouping them such as economic (creating employment possibilities), social and ethical implications by reason of aligning CSR information with the presented literature. 


\section{Findings}

The findings of the research are outlined as findings of normality and reliability tests, the correlations of the social and environmental responsibility image items and the differences in purchase intentions depending on the social and environmental responsibility image of corporates. For all tests, type 1 error level as .05 is accepted.

\subsection{Findings of Normality and Reliability Tests}

Kolmogorov Smirnov test was employed to analyze whether Likert items are distributing normally. Table 2 presents the numbers of samples and statistical results based on the banking, communication and air transportation markets. Findings reveal that none of the items distributed normally. Therefore, it was decided to utilize non-parametric tests.

Table 2. Findings of Normality Tests According to Markets

\begin{tabular}{|c|c|c|c|c|}
\hline Market & Items & 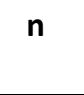 & $\begin{array}{l}\text { K-Smirnov } \\
\text { Z }\end{array}$ & $\mathbf{p}$ \\
\hline \multirow[t]{3}{*}{ Banking } & $\begin{array}{l}\text { Company seems to make an effort to create } \\
\text { new jobs (economic obligation). }\end{array}$ & 208 & .235 & $\leq .001$ \\
\hline & $\begin{array}{l}\text { Company seems to be environmentally } \\
\text { responsible (social obligation). }\end{array}$ & 208 & .294 & $\leq .001$ \\
\hline & $\begin{array}{l}\text { Company would reduce its profits to ensure a } \\
\text { clean environment (ethical obligation). }\end{array}$ & 208 & .280 & $\leq .001$ \\
\hline \multirow[t]{3}{*}{ Communication } & $\begin{array}{l}\text { Company seems to make an effort to create } \\
\text { new jobs (economic obligation). }\end{array}$ & 266 & .228 & $\leq .001$ \\
\hline & $\begin{array}{l}\text { Company seems to be environmentally } \\
\text { responsible (social obligation). }\end{array}$ & 266 & .222 & $\leq .001$ \\
\hline & $\begin{array}{l}\text { Company would reduce its profits to ensure a } \\
\text { clean environment (ethical obligation). }\end{array}$ & 266 & .234 & $\leq .001$ \\
\hline \multirow[t]{3}{*}{$\begin{array}{l}\text { Air } \\
\text { Transportation }\end{array}$} & $\begin{array}{l}\text { Company seems to make an effort to create } \\
\text { new jobs (economic obligation). }\end{array}$ & 206 & .210 & $\leq .001$ \\
\hline & $\begin{array}{l}\text { Company seems to be environmentally } \\
\text { responsible (social obligation). }\end{array}$ & 206 & .209 & $\leq .001$ \\
\hline & $\begin{array}{l}\text { Company would reduce its profits to ensure a } \\
\text { clean environment (ethical obligation). }\end{array}$ & 206 & .221 & $\leq .001$ \\
\hline
\end{tabular}

*Parameters of CSR do not distribute normally $(p=.000, p \leq .05)$

After the data collection, a secondary reliability test was examined in due to being sure about the reliability of research sample. Cronbach Alpha value was calculated as .850 .

\subsection{Correlations of the Social and Environmental Responsibility Image Items}

Spearman's Rank Order Correlation tests were done and according to findings there are positive and meaningful relations among social and environmental responsibility image items. Table 3 shows the related findings. 
The Effects of Social Responsibility Activities on Stakeholders' Purchase Intention

Table 3. Findings of Spearman's Rank Order Correlation Tests According to Markets

\begin{tabular}{lllll}
\hline Market & Items* & $\mathbf{N}$ & $\mathbf{r}$ & $\mathbf{p}$ \\
\hline Banking & Q1-Q2 & 208 & .640 & $\leq .001$ \\
& Q1-Q3 & 208 & .569 & $\leq .001$ \\
& Q2-Q3 & 208 & .743 & $\leq .001$ \\
\hline Communication & Q1-Q2 & 266 & .700 & $\leq .001$ \\
& Q1-Q3 & 266 & .644 & $\leq .001$ \\
& Q2-Q3 & 266 & .774 & $\leq .001$ \\
\hline Air & Q1-Q2 & 206 & .495 & $\leq .001$ \\
Transportation & Q1-Q3 & 206 & .435 & $\leq .001$ \\
& Q2-Q3 & 206 & .689 & $\leq .001$ \\
\hline *Correlations among scale items are significantly meaningful $(\mathrm{p}=.000, \mathrm{p} \leq .05)$
\end{tabular}

\subsection{Differences in Purchase Intention Depending on the Social and Environmental Responsibility Image of Corporates}

According to the content analysis of these statements, Akbank, Türkiye İş Bankası and Yapı Kredi Bankası conduct CSR activities on art, sustainability, education, social solidarity (e.g. aid after floods, earthquakes etc.) and ethical business implications. In addition, Garanti Bankası has also developed a different kind of CSR program on creating employment possibilities for handicapped citizens.

Table 4. Differences in Stakeholders' Purchase Intention Depending on the Social and Environmental Responsibility Image of Banks

\begin{tabular}{|c|c|c|c|c|c|c|}
\hline Market & Item & $\begin{array}{l}\text { Purchase } \\
\text { Intention }\end{array}$ & $\mathrm{n}$ & $\mathbf{R}$ & $\chi^{2}$ & $\mathbf{p}$ \\
\hline \multirow[t]{18}{*}{ Banking } & \multirow{6}{*}{$\begin{array}{l}\text { Company seems to make an } \\
\text { effort to create new jobs } \\
\text { (economic obligation). }\end{array}$} & 1 & 45 & 96.90 & 30.065 & $\leq .001$ \\
\hline & & 2 & 36 & 93.17 & & \\
\hline & & 3 & 51 & 82.30 & & \\
\hline & & 4 & 40 & 114.49 & & \\
\hline & & 5 & 36 & 145.68 & & \\
\hline & & Total & 208 & & & \\
\hline & \multirow{6}{*}{$\begin{array}{l}\text { Company seems to be } \\
\text { environmentally responsible } \\
\text { (social obligation). }\end{array}$} & 1 & 45 & 89.50 & 36.883 & $\leq .001$ \\
\hline & & 2 & 36 & 85.58 & & \\
\hline & & 3 & 51 & 88.01 & & \\
\hline & & 4 & 40 & 121.01 & & \\
\hline & & 5 & 36 & 147.18 & & \\
\hline & & Total & 208 & & & \\
\hline & \multirow{6}{*}{$\begin{array}{l}\text { Company would reduce its } \\
\text { profits to ensure a clean } \\
\text { environment (ethical } \\
\text { obligation). }\end{array}$} & 1 & 45 & 92.43 & 26.435 & $\leq .001$ \\
\hline & & 2 & 36 & 87.44 & & \\
\hline & & 3 & 51 & 89.81 & & \\
\hline & & 4 & 40 & 119.83 & & \\
\hline & & 5 & 36 & 140.42 & & \\
\hline & & Total & 208 & & & \\
\hline
\end{tabular}


In the communication market, Turkcell, Vodafone and Türk Telekom runs CSR activities with the themes of cultural, education, art and sport. They have also special focal groups who has varied handicaps.

Turkish Airlines and Pegasus conduct CSR programs on art, sustainability, education, social solidarity (e.g. aid after floods, earthquakes etc.), ethical business implications and varied aid campaigns for schools in poor villages, with a focal group that can be outlined as children and handicapped people.

Kruskal Wallis $\mathrm{H}$ tests were employed to test whether purchasing intention of stakeholders differ depending on the social and environmental responsibility image of corporates. Statistically meaningful differences were found for all markets as seen in Table 4, Table 5 and Table 6.

In Table 4, stakeholders who always purchase indicated banks' products/ services believe that the corporate is liable to make effort for creating new jobs, to take responsibility on environmental issues and to reduce its profits to ensure a clean environment $\left(p^{S 1} \leq .001, U^{S 1}=30.065 ; p^{S 2} \leq .001, U^{S 2}=36.883 ; p^{S 3} \leq .001\right.$, $U^{S 3}=26.435$ ). The results show that as the image of social and environmental responsibility weakens in the eye of stakeholders, the intention of purchasing diminishing.

In Table 5, stakeholders who often purchase the products/ services of indicated communication company believe that the corporate is liable to take responsibility on environmental issues and to reduce its profits to ensure a clean environment $\left(p^{S 2}=.003, U^{S 2}=15.808 ; p^{S 3}=.009, U^{S 3}=13.527\right)$. In this market, responsibility for creating employment possibilities seems more irrelevant or insignificant for the stakeholders. Moreover, similarly to banking market, results indicate that as the image of social and environmental responsibility weakens in the eye of stakeholders, the intention of purchasing diminishing.

Table 5. Differences in Stakeholders' Purchase Intention Depending on the Social and Environmental Responsibility Image of Communication Corporates

\begin{tabular}{|c|c|c|c|c|c|c|}
\hline Market & Item & $\begin{array}{l}\text { Purchase } \\
\text { Intention }\end{array}$ & $\mathrm{n}$ & $\mathbf{R}$ & $\chi^{2}$ & p \\
\hline \multirow[t]{18}{*}{ Communication } & \multirow{6}{*}{$\begin{array}{l}\text { Company seems to make an } \\
\text { effort to create new jobs } \\
\text { (economic obligation). }\end{array}$} & 1 & 36 & 109.79 & \multirow[t]{6}{*}{8.310} & \multirow[t]{6}{*}{.081} \\
\hline & & 2 & 63 & 125.45 & & \\
\hline & & 3 & 102 & 136.69 & & \\
\hline & & 4 & 48 & 150.94 & & \\
\hline & & 5 & 17 & 145.18 & & \\
\hline & & Total & 266 & & & \\
\hline & \multirow{6}{*}{$\begin{array}{l}\text { Company seems to be } \\
\text { environmentally responsible } \\
\text { (social obligation). }\end{array}$} & 1 & 36 & 106.94 & \multirow[t]{6}{*}{15.808} & \multirow[t]{6}{*}{.003} \\
\hline & & 2 & 63 & 139.22 & & \\
\hline & & 3 & 102 & 123.08 & & \\
\hline & & 4 & 48 & 162.72 & & \\
\hline & & 5 & 17 & 148.53 & & \\
\hline & & Total & 266 & & & \\
\hline & \multirow{6}{*}{$\begin{array}{l}\text { Company would reduce its } \\
\text { profits to ensure a clean } \\
\text { environment (ethical } \\
\text { obligation). }\end{array}$} & 1 & 36 & 113.42 & \multirow[t]{6}{*}{13.527} & \multirow[t]{6}{*}{.009} \\
\hline & & 2 & 63 & 136.21 & & \\
\hline & & 3 & 102 & 125.41 & & \\
\hline & & 4 & 48 & 165.42 & & \\
\hline & & 5 & 17 & 124.38 & & \\
\hline & & Total & 266 & & & \\
\hline
\end{tabular}


According to Table 6, stakeholders who often and always purchase the products/ services of indicated airline company believe that the corporate is liable to make effort for creating new jobs and to take responsibility on environmental issues respectively $\left(p^{S 1}=.003, U^{S 1}=16.360 ; p^{S 2}=.004, U^{S 2}=15.384\right)$. In this market, sacrificing from its profit for creating more clean natural environment looks like more irrelevant or insignificant for the stakeholders. On the other side, similarly to other markets, results indicate that there is a positive relationship between the image of social and environmental responsibility and the intention of purchasing.

Table 6. Differences in Stakeholders' Purchase Intention Depending on the Social and Environmental Responsibility Image of Air Transportation Corporates

\begin{tabular}{|c|c|c|c|c|c|c|}
\hline Market & Item & $\begin{array}{l}\text { Purchase } \\
\text { Intention }\end{array}$ & $n$ & $\mathbf{R}$ & $\chi^{2}$ & $\mathbf{p}$ \\
\hline \multirow{18}{*}{$\begin{array}{l}\text { Air } \\
\text { Transportation }\end{array}$} & \multirow{6}{*}{$\begin{array}{l}\text { Company seems to make an } \\
\text { effort to create new jobs } \\
\text { (economic obligation). }\end{array}$} & 1 & 10 & 73.95 & \multirow[t]{6}{*}{16.360} & \multirow[t]{6}{*}{.003} \\
\hline & & 2 & 47 & 83.00 & & \\
\hline & & 3 & 77 & 106.38 & & \\
\hline & & 4 & 52 & 124.30 & & \\
\hline & & 5 & 20 & 101.30 & & \\
\hline & & Total & 206 & & & \\
\hline & \multirow{6}{*}{$\begin{array}{l}\text { Company seems to be } \\
\text { environmentally responsible } \\
\text { (social obligation). }\end{array}$} & 1 & 10 & 89.45 & \multirow[t]{6}{*}{15.384} & \multirow[t]{6}{*}{.004} \\
\hline & & 2 & 47 & 100.82 & & \\
\hline & & 3 & 77 & 89.51 & & \\
\hline & & 4 & 52 & 116.36 & & \\
\hline & & 5 & 20 & 137.28 & & \\
\hline & & Total & 206 & & & \\
\hline & \multirow{6}{*}{$\begin{array}{l}\text { Company would reduce its } \\
\text { profits to ensure a clean } \\
\text { environment (ethical } \\
\text { obligation). }\end{array}$} & 1 & 10 & 92.30 & \multirow[t]{6}{*}{9.169} & \multirow[t]{6}{*}{.057} \\
\hline & & 2 & 47 & 95.43 & & \\
\hline & & 3 & 77 & 96.47 & & \\
\hline & & 4 & 52 & 112.10 & & \\
\hline & & 5 & 20 & 132.80 & & \\
\hline & & Total & 206 & & & \\
\hline
\end{tabular}

\section{Discussion and Conclusion}

It is assumed that cost-based strategic planning of social, economic or ethical obligations are crucial but not necessity for non-profit organizations. They generally plan and operate CSR activities for sharing acquisitions among stakeholders in a manner of social benefit whereas for-profit organizations should structure these activities as long-term strategies for sustaining a balance.

The contingency approach of CSR posits that the nature of CSR involvement would vary according to the external factors, market and firm structures and processes (Husted, 2000). In a global market, banking, air transportation and communication businesses have both some similar and distinctive circumstances according to geographic location which they operate. In Turkey, these businesses not only struggle with vulnerable economic and politic environment, but also have to show maximum effort to convince stakeholders that they are willing to share their relative astronomic incomes. In addition, they are face to face with stakeholders whose values, beliefs and life styles have transformed in different ways. These factors draw a complex external environment which leads corporates to act strategically and spontaneously. 
As the transformation of the societies' values, businesses feel obligated to engage in socially responsible behaviors in due to both satisfying stakeholder expectations and achieving competitive advantage. Within this context, CSR activities can be considered as social obligations, stakeholder obligations, ethical obligation or managerial responsiveness. The main difference of these perspectives is the focal point. It is suggested that social obligations, stakeholder obligations and ethical obligation deal with the positive effects of CSR on business activities in general terms whereas the perspective of managerial responsiveness concerns effective managing of CSR activities (Ackerman, 1975).

This research aimed to analyze the effects of social and environmental responsibility image on the purchase intention by integrating the perspectives of both social and shareholder obligations. The results reveal that reflections of CSR image can differ according to the market which corporates compete. In the banking market, both making efforts for creating new jobs (economic obligation), taking responsibility on environmental issues (social obligation) and reducing its profits to ensure a clean environment (ethical obligation) are valuable in the eye of most significant stakeholder groups. These banks' customers, employees, and people who have never purchased products/ services of these banks do their choices depending on the social, environmental and ethical CSR activities.

Most of the banks consider environmental issues not only as threats, but also as an opportunity to foresee potential future financial risks that should be avoided. As Labatt and the others (2002) indicated, financial markets monitor social and environmental issues associated with financial risks in terms of an environmental risk assessment of financial products. Goldstein (2001) warned that the lack of relevant information causes two significant drawbacks such as the under-funding of economic activities and the increase of productive capabilities among organizations in the private sector as well as limiting the competitive advantage of CSR activities.

As mentioned, banks may face to environmental issues as potential risks or as opportunities to develop new financial products. Environmental risks found for instance in polluting firms (e.g. the chemical industry) might cause financial liabilities to banks in the condition of lending money to those businesses. According to Thompson (1998), these risks are labeled as direct risk (e.g. legal liability for cleaning up contamination transferred from the insolvent borrower), indirect risk (e.g. the weakness of borrowers to repay their loan due to their financial responsibilities after environmental damage), and reputation risks (e.g. negative public relations due to doing business with environmentally unfriendly firms). In light of these arguments, Akbank, Garanti Bankası, Türkiye İ̧ Bankası, Yapı Kredi Bankası in Turkey can be admitted as the effective ones for creating successful halo effects by their CSR activities. In the air transportation and communication markets, creating employment possibility is perceived as unnecessary by stakeholders. According to them, responsibility for creating employment possibilities is not a relevant or significant expectation for communication businesses. The reason of this judgment can be arisen from the unhealthy effects of the mobile phones and the base stations on earth, which is known as the most common and important concerns among the stakeholders. Therefore, economic obligations may be not seen as vital in the eye of stakeholders.

Moreover, Chen and others (2012) conducted a research on the customers' perceptions of Taiwanese airline businesses social responsibility and its effects on loyalty. They found that airline social responsibility has a marginally significant and positive association with behavioral and attitudinal loyalty. According to participants, safety is found to be the most significant concern of customers, followed by consumer rights, environmental protection and social participation. Also Wang and the others (2015), found that most of the larger state-controlled Chinese airlines generate better performance of CSR whereas the private airline has made relatively large improvement.

Moreover, this research indicates that sacrificing from its profit for creating more clean natural environment is also irrelevant for the air transportation businesses. It can be caused by the economical position of this market. In Turkey there are only limited number of airline companies and they have been also suffering from the wild competition and turbulent economic conditions. There is also no report about a fatal 
airline crash which changes consumers' affect and attitudes toward the company in first place as mentioned Jorgensen (1994).

According to the results, these businesses may be accepted as effective in terms of the image of their CSR activities even they seem that do not plan and decide related activities in a manner of competitive advantage. The content analysis show that most of the businesses target the same groups with the similar activities. Therefore, they cannot balance both external obligations and their profit-oriented considerations unless they differentiate their brands by defining the most necessary social, economic and ethical obligations towards distinctive groups in their markets. For example, businesses in communication market may primarily develop ethical obligation-oriented programs on unhealthy outcomes of mobile phones and base stations. Thereby, future researches may aim identifying the pre-emptible obligations and their sub-headings with a sample composed of the most important stakeholders.

\section{References}

Ackerman, R. W. (1975). The social challenge to business. MA: Harvard University Press, Cambridge.

Andrews M., Luo X., Fang Z., \& Aspara J. (2014). Cause marketing effectiveness and the moderating role of price discounts. Journal of Marketing, 78, 120-142.

Auger, P., Devinney, T. M., Louviere, J. J., \& Burke, P. F. (2008). Do social product features have value to consumers? International Journal of Research Marketing, 25, 183-191.

Bansal, P., \& Roth, K. (2000). Why companies go green: A model of ecological responsiveness. Academy of Management Journal, 43(4), 717-736.

Brown, T. J., \& Dacin, P. A. (1997). The company and the product: Corporate associations and consumer product responses. Journal of Marketing, 61(1), 68-84.

Carrington, M. J., Neville B. A., \& Whitwell, G. J. (2014). Lost in translation: Exploring the ethical consumer intentionbehavior gap. Journal of Business Research, 67, 2759-2767.

Carroll, A. B. (1979). A three-dimensional conceptual model of corporate performance? Academy of Management Review, 4(4), 497-505.

Chen, F. Y., Chang, Y. H., \& Lin, Y. H. (2012). Customer perceptions of airline social responsibility and its effect on loyalty. Journal of Air Transport Management, 20, 49-51.

Chernev, A., \& Blair, S. (2015). Doing well by doing good: The benevolent halo of corporate social responsibility. Journal of Consumer Research, 41, 1412-1425.

Clarkson, M. B. E. (1995). A stakeholder framework for analyzing and evaluating corporate social performance? Academy of Management Review, 20(1), 92-117.

Coupland, C. (2006). Corporate social and environmental responsibility in web-based reports: Currency in the banking sector? Critical perspectives on Accounting, 17(7), 865-881.

Demirgüneş, B. K. (2015). Sosyal sorumluluk projelerine yönelik tutumun, satın alma davranışı ve satın alma niyeti üzerindeki etkisi. Hacettepe Üniversitesi Iktisadi ve Idari Bilimler Fakültesi Dergisi, 33(3).

Donaldson, T., \& Preston, L. E. (1995). The stakeholder theory of the corporation: Concepts, evidence and implications? Academy of Management Review, 29 (January), 65-91.1.

Drumwright, M. (1994). Socially responsible organizational buying: Environmental concern as a non-economic buying criterion. Journal of Marketing, 58(3), 1-19.

Du, S., Sen, S., \& Bhattacharya, C. B. (2008). Exploring the social and business returns of a corporate oral health initiative aimed at disadvantaged hispanic families. Journal of Consumer Research, 35, 483-494.

Du, S., Bhattacharya, C. B., \& Sen, S. (2011). Corporate social responsibility and competitive advantage: Overcoming the trust barrier. Manage Science, 57, 1528-1545.

Evangelinos, K. I., Skouloudis, A., Nikolaou, I. E., \& Leal Filho, W. (2009). An analysis of corporate social responsibility (CSR) and sustainability reporting assessment in the Greek banking sector. In Professionals' Perspectives of Corporate Social Responsibility (pp. 157-173). Berlin, Heidelberg: Springer.

Fombrun, C. J., Van Riel, C. B., \& Van Riel, C. (2004). Fame \& fortune: How successful companies build winning reputations. FT Press. 
Freeman, R.E. (1984). Strategic Management: A Stakeholder Approach. Boston: Pitman.

Goldstein, D. (2001). Financial sector reform and sustainable development: The case of Costa Rica. Ecological Economics, 37, 199-215.

Henderson T., \& Arora, N. (2010). Promoting brands across categories with a social cause: Implementing effective embedded premium programs. Journal of Marketing, 74, 41-60.

Henriques, I., \& Sadorsky, P. (1999). The relationship between environmental commitment and managerial perceptions of stakeholder importance. Academy of Management Journal, 42(1), 89-99.

Husted, B. W. (2000). A contingency theory of corporate social performance. Business and Society, 39, 24-48.

Janssen, C., Sen, S., \& Bhattacharya, C. B. (2015). Corporate crises in the age of corporate social responsibility. Business Horizons, 58(2), 183-192.

Jorgensen, B. (1994). Consumer reaction to company-related disasters: The effect of multiple versus single explanations. Advances in consumer research, 21(1), 348-352.

Kardeş, í. (2011). Markaların çevre dostu uygulamalarının tüketicinin marka tercihi üzerindeki etkisi. Ege Akademik Bakış Dergisi, 11(1), 165-177.

Klein, J., \& Dawar, N. (2004). Corporate social responsibility and consumers' attributions and brand evaluations in a product-harm crisis. International Journal of Research in Marketing, 21(3), 203-217.

Kotler, P., Hessekiel, D., \& Lee, N. (2012. Good works! Marketingand corporate initiatives that build a better world. . .and the bottom line. Hoboken, NJ: John Wiley \& Sons.

Krishna, A., \& Rajan, U. (2009). Cause marketing: spillover effects of cause related products in a product portfolio. Management Science, 55, 1469-1485.

Labatt, S., White, R. R., \& Cooper, G. (2002). Environmental finance: A guide to environmental risk assessment and financial products. London: Wiley \& Sons.

Maignan, I., \& Ralston, D. A. (2002). Corporate social responsibility in Europe and the US: Insights from businesses' selfpresentations. Journal of International Business Studies, 33(3), 497-514.

Menon, S., \& Kahn, B.E. (2003). Corporate sponsorships of philanthropic activities: When do they impact perception of sponsor brand? Journal of Consumer Psychology, 13, 316-327.

O'Donovan, G. (2002). Environmental disclosures in the annual report: Extending the applicability and predictive power of legitimacy theory. Accounting, Auditing and Accountability Journal, 15, 344-71.

Özdemir, H. (2009). Kurumsal sosyal sorumluluğun marka imajına etkisi. İstanbul Ticaret Üniversitesi Sosyal Bilimler Dergisi, 8(15), 57-72.

Öztürk, G., \& Özdemir Çakır, H. (2014). The effect of corporate reputation on buying behaviour and brand loyalty: A research on SHELL\&TURCAS corporation. E- Journal of Intermedia, 1(1), 107-117.

Porter, M. E., \& Kramer, M. R. (2011). The big idea: Creating shared value. Harvard Business Review, 89(1/2), 62-77.

Sen, S., \& Bhattacharya, C. B. (2001). Does doing good always lead to doing better? Consumer reactions to corporate social responsibility. Journal of Marketing Research, 38(2), 225-243.

Sen, S., Du, S., \& Bhattacharya, C. B. (2016). Corporate social responsibility: A consumer psychology perspective. Current Opinion in Psychology, 10, 70-75.

Servaes, H., \& Tamayo, A. (2013). The impact of corporate social responsibility on firm value: The role of customer awareness. Management Science, 59, 1045-1061.

Swanson, D. L. (1995). Addressing a theoretical problem by reorienting the corporate social performance model? Academy of Management Review, 20(1), 43-64.

Thompson, P. (1998). Bank lending and the environment: Policies and opportunities. International Journal of Bank Marketing, 16(6), 243-252.

Trudel, R., \& Cotte, J. (2009). Does it pay to be good? MIT Sloan Manage Review, 5, 61-68.

Wang, Q., Wu, C., \& Sun, Y. (2015). Evaluating corporate social responsibility of airlines using entropy weight and grey relation analysis. Journal of Air Transport Management, 42, 55-62.

Wartick, S. L., \& Cochran, P. L. (1985). The evolution of the corporate social performance model. Academy of Management Review, 10(4), 758-769.

Wood, D. J. (1991). Corporate social performance revisited. Academy of Management Review, 16(4), 691-718. 
Yorulmazer, G., \& Doğan, O. (2017). turizm işletmelerindeki kurumsal sosyal sorumluluk uygulamalarinin satin alma niyeti üzerindeki etkileri: Turistlere yönelik bir araştirma. Gümüshane University Electronic Journal of the Institute of Social Science/Gümüshane Üniversitesi Sosyal Bilimler Enstitüsü Elektronik Dergisi, 8(21). 